\title{
M-Learning Boost Students' Motivation in Learning Arabic Language Proficiency for Elementary Level
}

\author{
Wan Ab Aziz Wan Daud ${ }^{1}$, Wong Kung Teck ${ }^{2, *}$, Mohammad Taufiq Abdul Ghani ${ }^{3}$, Saipolbarin Ramli ${ }^{3}$ \\ ${ }^{1}$ Center for Languages and Generic Development, Universiti Malaysia Kelantan, Malaysia \\ ${ }^{2}$ Faculty of Human Development, Universiti Pendidikan Sultan Idris, Malaysia \\ ${ }^{3}$ Faculty of Languages and Communication, Universiti Pendidikan Sultan Idris, Malaysia
}

Received May 5, 2020; Revised June 17, 2020; Accepted August 10, 2020

\begin{abstract}
Cite This Paper in the following Citation Styles
(a): [1] Wan Ab Aziz Wan Daud, Wong Kung Teck, Mohammad Taufiq Abdul Ghani, Saipolbarin Ramli, "M-Learning Boost Students' Motivation in Learning Arabic Language Proficiency for Elementary Level," Universal Journal of Educational Research, Vol. 8, No. 10, pp. 4384-4392, 2020. DOI: 10.13189/ujer.2020.081004.
\end{abstract}

(b): Wan Ab Aziz Wan Daud, Wong Kung Teck, Mohammad Taufiq Abdul Ghani, Saipolbarin Ramli (2020). M-Learning Boost Students' Motivation in Learning Arabic Language Proficiency for Elementary Level. Universal Journal of Educational Research, 8(10), 4384-4392. DOI: 10.13189/ujer.2020.081004.

Copyright $\bigcirc 2020$ by authors, all rights reserved. Authors agree that this article remains permanently open access under the terms of the Creative Commons Attribution License 4.0 International License

\begin{abstract}
The language acquisition is one of the most important criteria that contribute to the measurement of language proficiency for students and the objectives of teaching of Arabic in Malaysia are currently based on the Standard Arabic Curriculum, which focuses on mastery of the four language skills. However, the inability to master the four language skills is still very significant. This occurs due to the fact that students only learn Arabic to pass the exam and that learning strategies applied to the students are less interactive and effective which led to demotivate the student to continue the learning process. Therefore, the primary purpose of this study is to examine the impact of mobile learning towards motivation in learning Arabic language proficiency. The research focuses on analysing the participants' motivation regarding the education of Arabic language in particular, via mobile learning. The attention, relevance, confidence, and satisfaction (ARCS) model shaped the comprehension of the effect of education through mobile app towards the motivation of the respondents. A total of 273 participants in Malaysians Higher Institutions used mobile learning for Arabic language proficiency during teaching and learning process. After this, they will complete the motivation questionnaire. The results showed that attention, relevance, satisfaction, and confidence motivational factors had a significant impact on student's motivation to learn Arabic through mobile app. Hence, this study contributes to the significant empirical results on the effectiveness of the integration of ARCS model in mobile app for learning
\end{abstract}

Arabic language.

Keywords Motivation, ARCS Model, Arabic language, Language Proficiency, Mobile Learning

\section{Introduction}

Mobile learning is an opportunity for communities from all across the globe to broaden their education free of charge without any limitations. The increasing figures of mobile learning education have greatly contributed to an increasing amount of research exploring different elements of online learning. M-learning poses a completely new learning environment for students, particularly engineering students and therefore requires varied expertise set to become effective (Ally \& Prieto-Blázquez, 2014). M-learning can be characterised as ICT-based education or training, personalised, scalable, versatile, individual, self-organised, cooperative education, guided by a community of learners, educators, facilitators, professionals, etc. (Kim et al., 2013). In this situation, students were, in fact, in courses that were completely electronic; making students more autonomous than in the conservative environment. In the context of the aforementioned, this research deals with the analysis of the impact of mobile learning boost students' motivation in learning Arabic language proficiency. The variables under 
study are the Arabic treatment group students in using mobile learning.

\subsection{Motivation to Learn Arabic Language}

Motivation is defined as an incentive to act and to maintain the intention to achieve the desired objectives (Ames \& Ames, 1989). Oxford \& Shearin (1994) believed that it is a crucial aspect which dictates the depths to which personal participation, activity and achievement in the mastery of the second language have already been attained. Motivation, as such, is a valuable force because it is an internal force that drives action and maintains the goals of a person. Continuous efforts and objectives will ultimately lead to success in achieving what is needed.

Several studies have found that motivating elements make a significant contribution to students' achievement in second language study (Lightbown \& Spada, 1999). In the context of educational training of Arabic language, Misnan Jemali (1999) stated that the connection between motivation and accomplishment of students in learning Arabic language communication has been found to be significant. Nik Mohd Rahimi et al. (2009) acknowledge that there is a strong connection between motivation and students' performance in Arabic language learning, where the better the motivation of students, the more progress they have made in Arabic language learning. Siti Sukainah Melor (2014) concludes that positive behaviour, motivation and mastery of the target language are essential factors that affect the progress of language students. It is therefore utmost vital for us to figure out exactly what are the reasons behind the determination and motivation for learning a second language. Understanding and awareness of these factors can provide useful guidance for determining the principles of the Arabic language curriculum being planned and implemented.

According to Mohammad Shatar (2005), motivation is the core for learning process to occur. Motivation not only drives behaviour but also directs and reinforces the learning behaviour of motivated learners and has a high level of interest, enthusiasm and diligence in teaching, with little dependence on educators or others. Therefore, with motivation, students are able to gain happiness and enjoyment in educational experiences. Apart from that, they will appreciate the importance of learning Arabic in their life.

Noels (2002) distinguishes the factors that make up the motivation for the two categories, the first of which is intrinsic orientations relating either to happiness and enjoyment because of knowledge growth, accomplishment or knowledge gain. The second is the extrinsic orientation that arises as a result of external returns, such as graduation, employment, gifts, and so on. Ellis (1985), Julkunen (1989) and Dornyei (1994) stressed that the motivation towards the second language of students could be affected by learning experiences, teaching materials, and individual tasks. Oxford \& Shearin (1994) identified six factors that have a significant impact on motivation growth, including attitudes toward target language, self-esteem, objectives, commitment, atmosphere and self-attributes. Abbas et al. (2012) gave a very interesting look where he described that passion is the most important factor in creating motivation.

Acquisition and achievement of Arabic language learning in Malaysia as a whole are not yet satisfactory and has not yet been achieved. It is arguable that Malaysia's achievement of Arabic language students is still at a point that cannot be proud of either at school or in higher education institutions. Many complaints and grievances have been raised by educators and learners of Arabic language lessons of the past about students' weakness in mastering Arabic.

Many of the views expressed by the researchers relate to the weakness of the achievement of Arabic language among students with their level of motivation. Siti Saudah (1994) argues that the problem that affects the weakness of Arabic language acquisition is a language atmosphere that does not motivate students. Arabic does not have a strong and supportive environment as this language is not used regularly in daily contact and is considered hard to understand. Consequently, the Arabic language's residual atmosphere is considered a means of undermining the motivation of Arabic language students. Sofian \& Zainal Abidin (1986) referred to the weakness of the students in Arabic learning due to their low motivation, which they find to be a difficult issue. Osman Khalid (1993) notes that many Arabic language students are less interested and motivated by their weak motivation, so few students take advantage of the facilities provided to learn Arabic such as language lab, film, magazine, newspaper and periodicals in Arabic. Zamri Ariffin et al. (2014) stressed that some of the key reasons that led many students to skip or struggle to study Arabic in Malaysia were their behaviour and mindset to the Arabic language itself. The percentage of Arabic language usage among students inside or outside the classroom is too high. This illustrates that the motivation and usage of the Arabic language among students are low (Ab. Halim \& Wan Mohammad, 2006).

In the context of the weakness of the Arabic language and the deterioration of the motivational level of the students; Noriati et al. (2009) suggested that teachers should always interact with students using Arabic, practice interesting teaching techniques and use a variety of learning materials. Abdul Hakim (1998) suggests that the content of lessons, learning materials, teaching methods and assessment materials should be streamlined so that the motivation and use of Arabic language among students can be overcome. Vos Nienke et. al. (2011) notes that the development of new games will boost student motivation and deep learning. Muhammad Sabri \& Nor Aziah (2009) study also agreed on this idea, which 
suggested that online Arabic language games should be improved after finding the average students agree that online Arabic language games would improve their attitudes, motivation and achievement in language learning Arabic. Abdul Hakim et al. (2015) show that the high level of student motivation is a central element in the progress of student achievement in Arabic. The better the students ' motivation for the Arabic language, the higher the student achievement in the Arabic language.

Muhamad Najib (2014) conducted a study on the behaviour and motivation of IPT learners towards the Arabic Language Teaching Module. This study focuses on the behaviour and motivation of IPT undergraduates in Malaysia towards the Arabic teaching modules in terms of tourism. Among the findings, are the percentage of attitudes and motivation the Arabic language teaching module is high at $90 \%$. The effectiveness of the Arabic language teaching modules is also well-positioned through surveys of respondents from three HEIs, Universiti Sains Islam Malaysia (USIM), Universiti Teknologi Mara (UiTM) and Selangor Islamic University College (KUIS) which offers offering subjects of Arabic Tourism subjects.

Abdul Hakim (2015) conducted a study at Sekolah Menengah Kebangsaan Agama (SMKA) Naim Lilbanat, Kota Bharu Kelantan, on the elements which may influence motivation toward Arabic education amongst lower secondary students. The rise in the level of performance of students is dependent on factors that improve their motivation. His study identifies the motivating factors for Arabic language education among lower secondary school students at Sekolah Menengah Kebangsaan Agama (SMKA) Naim Lilbanat, Kota Bharu, Kelantan.

The results from this topic can be summarised that findings from previous research have shown that inspiration has facilitated learning in Arabic. The study also assumes that in addition to having non-motivational factors as support motivation and vice versa, a person with high inspirational motivation will achieve the goal of Arabic learning. Based on this study, the students' performance is expected to be driven by significant motivational approaches and demographic factors related to this study.

\subsection{Motivation in Mobile Learning}

According to Ally \& Prieto-Blázquez (2014), students must be strongly motivated and committed to studying with less social contact with classmates or teachers. Learners in mobile learning courses prefer to do the same thing in schools, however, there is a greater possibility of removal or unfinished marks. The successful implementation of mobile technology takes us closer than ever to personalised learning and thus offers the right preparation, training and success opportunities at the precise time and place for the exact individual (Sha, 2012). Mobile learning's true potential should not only be defined as educational material being distributed or retrieved on mobile devices.

Mobile learning may also be called computerised and collaboration learning pedagogy (Jacob, 2014). Recent M-learning innovations focused on smartphones in which a portion or even all of the educational material is presented digitally. The teaching and learning component of M-learning has recently become a common feature. M-learning covers every type of electronically aided education and communication system that function as basic media for the advancement of the learning process, whether networked or not. Internet technology allows multiple users to access digital content simultaneously, anytime and anywhere. The aspect of M-learning is that it standardises content and delivery of courses, as opposed to a lecture given for various areas of the same course. The administrative burden limits the faculty's monitoring and recording of learners (Jacob \& Issac, 2014).

In addition, M-learning may be expected to provide an assessment of outcomes to assess whether learning has taken place. Benefits of learning a better environment, which are less well known but could be more innovative aspect of M-learning than Martin \& Ertzberger (2013) in the arena of learning, learning via mobile technologies include an innovative paradigm constructed on theory of student learning that says that students learn in relation to new learning experience, through linkage of learning to real needs and through the practice of learning that results in more effectiveness and efficiency. Improvement learning allows for greater interaction and endorses the effectiveness, inspiration, intellectual efficiency and flexibility of learners' learning styles.

The effectiveness is expected to turn into increased performance and motivation. M-Learning has shown improved retention levels and improved use of material, allowing for the greater accomplishment of knowledge, skills, and behaviours, according to Martin \& Ertzberger (2013). Multimedia M-learning gives students the room to choose from a wide range of media selections to fit their various education styles. Using M-Learning, in general, will help them recall, read smoothly and easily, write, communicate and manage all four language skills necessary (Hsu, 2013). The introduction of M-Learning is expected to encourage students to improve the aptitudes, capacities and skills they possessed, especially in Arabic studies; hence they are able to prepare themselves to deal with the life of work in the future.

Mohammad Baihaqi (2017) studied Arabic as a second language for engineering students in M-Learning and its effects. The study was carried out at 30 University of Malaysia Pahang engineering students. The qualitative and quantitative approaches were used in this study. The article also provides advantages, disadvantages and examples of Arabic online platforms. M-learning is a ground-breaking method of educational approach, a relatively new concept. 
M-learning means education is not designed to a table of study only, nowadays students should have continuous access to information regardless of where they are.

Overall, for communication, in particular, mobile learning such as websites and apps has a positive impact on the Arabic learning process. With the latest software in technology designed to help students learn beyond the classroom and pursue learning elsewhere. From these previous studies, the researcher found that there are numerous benefits of applying mobile learning in the pedagogical process. The difference between these studies and the researcher's study varies in many ways; in the first study the field of English, while the researcher's field of study is the Arabic language that more focuses on the elementary level in Malaysia's HIEs students.

\section{The Methodology of the Study}

\subsection{Participants}

The target participants comprise of diploma and degree level learners who are taking Arabic language courses at the tertiary level in four public universities in Peninsular Malaysia for the academic year of 2018/2019. A total of 273 non-native Arabic speaker students participated in this study. A stratifies random sampling was used to select the public university in each peninsular zone. Then, a simple random sampling was performed to select the students to respond to the questionnaire.

\subsection{Instruments}

A motivational survey was carried out by administering a collection of questionnaires implemented from a previous study conducted by Loorbach et al. (2015). The items are based on ARCS motivational design model from Keller (1983). This questionnaire employs an interval scale and the students were instructed to rate each of the items from one to ten. The distribution of the items was summarised in the table as below:

Table 1. Motivation Questionnaire Item

\begin{tabular}{ccc}
\hline No & Components & No. of Item \\
\hline 1. & Attention & 12 \\
2. & Relevance & 9 \\
3. & Confidence & 9 \\
4. & Satisfaction & 6 \\
\hline
\end{tabular}

\subsection{Data Analysis}

The information collected was categorised as attention, relevance, confidence and satisfaction. The descriptive statistics for the data collected were employed by harnessing the IBM SPSS Statistics 25 software. The results were then presented in four sections according to the ARCS model.

\subsection{Pilot Study}

A pilot study was carried out on 140 students chosen randomly to acquire the data. The researcher employed the exploratory factor analysis so that it is easier to analyse and examine the dimensionality of items measuring construct in the research. After that, the study employed a reliability test to obtain the Alpha Cronbach value of the instrument. The results of the pilot study are as follows.

Table 2. The KMO and Bartlett's Test Score

\begin{tabular}{ccc}
\hline Kaiser-Meyer-Olkin Measure of Sampling Adequacy. & .903 \\
& Approx. Chi-Square & 2870.774 \\
Bartlett's Test of Sphericity & df & 595 \\
& Sig. & .000 \\
\hline
\end{tabular}

The Exploratory Factor Analysis (EFA) utilising the extraction method of Principal Component with Varimax (Variation Maximisation) Rotation was carried out on these 36 items measuring the Second Order Motivation. The results in Table 2 illustrate that the Bartletts' Test of Sphericity is substantial ( $\mathrm{P}-\mathrm{Value}<0.05$ ). Additionally, the measure of sampling adequacy by Kaiser-Meyer-Olkin (KMO) is outstanding since it surpassed the obligatory value of 0.6 (Awang, 2010, 2012; Hoque et al., 2015; and Noor et al., 2015). These two outcomes (Bartlett's Test is significant and $\mathrm{KMO}>0.6$ ) designate that the figures are acceptable to progress further with the data reduction practice in EFA (Awang, 2010, 2012; Noor et al., 2015; Hoque and Awang, 2016; Hoque et al., 2017, 2018; and Yahaya et al., 2018).

The following table, Table 3, shows the Four Dimensions or elements that had been developed from the EFA process and their corresponding products. The loading factor for each element should be larger than 0.5 so that it can be maintained (Awang, 2012; and Yahaya et al., 2018). The element of each part must then be omitted because it failed to fulfill the minimal loading factor criterion of 0.5 (Awang, 2010, 2012, 2014, \& 2015, Noor et al., 2015; Hoque and Awang, 2016; Hoque et al., 2017, 2018; and Yahaya et al., 2018). The omitted items (caused by low loading factor $<0.5$ ) and the preserved items can be seen in the chart provided. 
Table 3. The Components and Their Respective Items

\begin{tabular}{|c|c|c|c|c|}
\hline & \multicolumn{4}{|c|}{ Component } \\
\hline & 1 & 2 & 3 & 4 \\
\hline $\mathrm{A} 01$ & .637 & & & \\
\hline A02 & .532 & & & \\
\hline A03 & .523 & & & \\
\hline A04 & .596 & & & \\
\hline A05 & .609 & & & \\
\hline A06 & .592 & & & \\
\hline A07 & .534 & & & \\
\hline A08 & .575 & & & \\
\hline A09 & .547 & & & \\
\hline A10 & .554 & & & \\
\hline A11 & .667 & & & \\
\hline A12 & .662 & & & \\
\hline R02 & & .695 & & \\
\hline R03 & & .683 & & \\
\hline R04 & & .510 & & \\
\hline R05 & & .640 & & \\
\hline R06 & & .582 & & \\
\hline R07 & & .564 & & \\
\hline R08 & & .547 & & \\
\hline R09 & & .594 & & \\
\hline $\mathrm{C} 01$ & & & .543 & \\
\hline $\mathrm{C} 02$ & & & .710 & \\
\hline $\mathrm{C} 03$ & & & .562 & \\
\hline $\mathrm{C} 04$ & & & .609 & \\
\hline $\mathrm{C} 05$ & & & .589 & \\
\hline $\mathrm{C} 06$ & & & .572 & \\
\hline $\mathrm{C} 07$ & & & .568 & \\
\hline $\mathrm{C} 08$ & & & .661 & \\
\hline $\mathrm{C} 09$ & & & .555 & \\
\hline S01 & & & & .874 \\
\hline $\mathrm{S} 02$ & & & & .744 \\
\hline S03 & & & & .746 \\
\hline S04 & & & & .773 \\
\hline S05 & & & & .805 \\
\hline S06 & & & & .701 \\
\hline
\end{tabular}

Eventually, the research will require to calculate the value of Cronbach's Alpha to represents the Internal Reliability for the preserved components in measuring this Second Order Motivation. The internal reliability or internal consistency clearly shows how solid the respective items are holding to each other in evaluating the respective construct. The value of Cronbach's Alpha must be larger than 0.7 in order for items to obtain Internal Reliability
(Awang, 2012). Table 5 presented the Cronbach Alpha for each component.

Table 4. The Internal Reliability for the Financial Attitude Construct

\begin{tabular}{ccc}
\hline Component & No of Items & Cronbach's Alpha \\
\hline 1 & 12 & 0.889 \\
2 & 8 & 0.848 \\
3 & 9 & 0.851 \\
4 & 6 & 0.927 \\
\hline
\end{tabular}

\section{Results and Findings}

The results and findings are presented below.

\subsection{Construct: Attention (A)}

This study analyses the focus of the model in which the results are illustrated in the table below. It can be concluded from Table 5 that the participants had given their approval which related to the comments found in the following table. This is evident by the mean attained for reports $\mathrm{A} 01$ to $\mathrm{A} 12$ have values that range between $7.19 \pm 1.10$ to $7.63 \pm 1.20$.

Table 5. Attention

\begin{tabular}{|c|c|c|c|}
\hline No. & Items & Mean & SD \\
\hline A01 & $\begin{array}{l}\text { Something was interesting at the } \\
\text { beginning of this lesson that got my } \\
\text { attention. }\end{array}$ & 7.63 & 1.20 \\
\hline $\mathrm{A} 02$ & These materials are eye-catching. & 7.29 & 1.17 \\
\hline $\mathrm{A} 03$ & $\begin{array}{l}\text { The quality of the writing helped to } \\
\text { hold my attention. }\end{array}$ & 7.48 & 1.08 \\
\hline A04 & $\begin{array}{l}\text { This lesson is so abstract that it was } \\
\text { hard to keep my attention on it }\end{array}$ & 7.23 & 1.01 \\
\hline A05 & $\begin{array}{l}\text { The pages of this lesson look dry } \\
\text { and unappealing. }\end{array}$ & 7.27 & 0.98 \\
\hline A06 & $\begin{array}{l}\text { The way the information is } \\
\text { arranged on the pages helped keep } \\
\text { my attention. }\end{array}$ & 7.51 & 1.04 \\
\hline A07 & $\begin{array}{l}\text { This lesson has things that } \\
\text { stimulated my curiosity. }\end{array}$ & 7.21 & 1.08 \\
\hline A08 & $\begin{array}{l}\text { The amount of repetition in this } \\
\text { lesson caused me to get bored } \\
\text { sometimes. }\end{array}$ & 7.25 & 0.94 \\
\hline A09 & $\begin{array}{l}\text { I learned some things that were } \\
\text { surprising or unexpected. }\end{array}$ & 7.39 & 1.07 \\
\hline A10 & $\begin{array}{l}\text { The variety of reading passages, } \\
\text { exercises, illustrations, etc., helped } \\
\text { keep my attention on the lesson. }\end{array}$ & 7.45 & 1.10 \\
\hline A11 & The style of content is boring. & 7.23 & 1.00 \\
\hline A12 & $\begin{array}{l}\text { There are so many words on each } \\
\text { page that it is irritating. }\end{array}$ & 7.19 & 1.10 \\
\hline
\end{tabular}

\subsection{Construct: Relevance (R)}

The results of construct relevance indicate that overall, the participants agree with statements R02 to R09. This is 
corroborated by the fact that the participants agreed that there were stories, images, or exemplars showing how third-party materials might be relevant to some people (7.48 \pm 1.05$)$.

Moreover, the participants agree that completing the lesson successfully is essential to them (7.52 \pm 0.84$)$. The respondents generally accept that the material of this subject is appropriate to their desires and wishes (7.52 \pm 0.87$)$. From the table below, it can be established that the parties affected accept that there are some rationalisations or explanations of how individuals use the awareness of lessons, as shown by the mean of $7.45 \pm 0.88$. The study further shows that the respondents admit that the lesson's material and writing tone gives the illusion that its content is beneficial (7.45 \pm 0.89$)$. Lastly, it can be observed that the participants agree with the statements R07, R08, and R09 respectively as indicated by the mean of $7.28 \pm 1.02,7.45 \pm 0.91$, and $7.51 \pm 0.87$ respectively.

Table 6. Relevance

\begin{tabular}{llll}
\hline No. & \multicolumn{1}{c}{ Items } & Mean & SD \\
\hline R02 & $\begin{array}{l}\text { There were stories, pictures, or } \\
\text { examples that showed me how this } \\
\text { material could be relevant to some } \\
\text { people. } \\
\text { Completing this lesson successfully } \\
\text { was vital to me. }\end{array}$ & 7.48 & 1.05 \\
R03 & The content of this material is relevant \\
to my interests. & 7.52 & 0.84 \\
Rhere are explanations or examples of \\
how people use the knowledge in this \\
lesson.
\end{tabular}

\subsection{Construct: Confidence (C)}

The results in the table highlight the findings of the construct confidence. The findings indicate that the participants agree with statements $\mathrm{C} 01$ to $\mathrm{C} 09$. This is evident by the fact that all of the means in the table below are above average- ranging between $7.25 \pm 1.11$ to $7.79 \pm 1.30$.
Table 7. Confidence

\begin{tabular}{|c|c|c|c|}
\hline No. & Items & Mean & SD \\
\hline $\mathrm{C} 01$ & $\begin{array}{l}\text { When I first looked at this lesson, I had the } \\
\text { impression that it would be easy for me. }\end{array}$ & 7.79 & 1.30 \\
\hline $\mathrm{C} 02$ & $\begin{array}{l}\text { This material was more difficult to } \\
\text { understand than I would like for it to be. }\end{array}$ & 7.27 & 1.04 \\
\hline $\mathrm{C} 03$ & $\begin{array}{l}\text { After reading the introductory information, I } \\
\text { felt confident that I knew what I was } \\
\text { supposed to learn from this lesson. }\end{array}$ & 7.54 & 1.09 \\
\hline $\mathrm{C} 04$ & $\begin{array}{l}\text { Many of the pages had so much information } \\
\text { that it was hard to pick out and remember } \\
\text { the important points. }\end{array}$ & 7.41 & 1.07 \\
\hline $\mathrm{C} 05$ & $\begin{array}{l}\text { As I worked on this lesson, I was confident } \\
\text { that I could learn the content. }\end{array}$ & 7.61 & 1.05 \\
\hline $\mathrm{C} 06$ & $\begin{array}{l}\text { The exercises in this lesson were too } \\
\text { difficult. }\end{array}$ & 7.25 & 1.11 \\
\hline $\mathrm{C} 07$ & $\begin{array}{l}\text { After working on this lesson for a while, I } \\
\text { was confident that I would be able to pass a } \\
\text { test on it. }\end{array}$ & 7.45 & 1.10 \\
\hline $\mathrm{C} 08$ & $\begin{array}{l}\text { I could not really understand quite a bit of } \\
\text { the material in this lesson. }\end{array}$ & 7.29 & 1.03 \\
\hline $\mathrm{C} 09$ & $\begin{array}{l}\text { The good organization of the content helped } \\
\text { me be confident that I would learn this } \\
\text { material. }\end{array}$ & 7.53 & 1.07 \\
\hline
\end{tabular}

\subsection{Construct: Satisfaction (S)}

The construct satisfaction is analysed by the investigator; the discoveries are highlighted in the table below, Table 8. The results indicate that the participants agree that completing the lesson exercise gave them a satisfying sense of achievement. Moreover, the results suggest that they enjoyed the experience so much that they would like to know more about the topic $(7.91 \pm 0.96)$. The participants decide that they enjoy studying this lesson (7.82 \pm 1.00$)$. Furthermore, the participants agree that the phrasing of response or feedback right after the exercise or any other remarks in this lesson aided them to sense their efforts (7.69 \pm 1.07$)$. It can be established that the participants agree with statement S05 and S06, as illustrated by the mean attained of $7.84 \pm 1.03$ and $8.20 \pm 0.89$, respectively.

Table 8. Satisfaction

\begin{tabular}{|c|c|c|c|}
\hline No. & Items & Mean & SD \\
\hline S01 & $\begin{array}{l}\text { Completing the exercises in this lesson gave } \\
\text { me a satisfying feeling of accomplishment }\end{array}$ & 7.79 & 1.17 \\
\hline $\mathrm{S} 02$ & $\begin{array}{l}\text { I enjoyed this lesson so much that I would like } \\
\text { to know more about this topic. }\end{array}$ & 7.81 & 0.96 \\
\hline S03 & I enjoyed studying this lesson. & 7.82 & 1.00 \\
\hline S04 & $\begin{array}{l}\text { The wording of feedback after the exercises, or } \\
\text { of other comments in this lesson, helped me } \\
\text { feel rewarded for my effort. }\end{array}$ & 7.69 & 1.07 \\
\hline S05 & $\begin{array}{l}\text { It felt good to complete this lesson } \\
\text { successfully. }\end{array}$ & 7.84 & 1.03 \\
\hline S06 & $\begin{array}{l}\text { It was a pleasure to work on such a } \\
\text { well-designed lesson. }\end{array}$ & 8.20 & 0.89 \\
\hline
\end{tabular}


The correlation between ARCS component was performed using Pearson Correlation analysis as tabulated in the table below. The result of Pearson correlation indicated that there was a significant positive association between attention $(\mathrm{A})$ and confidence $(\mathrm{C})(\mathrm{r}(273)=0.580$, $\mathrm{p}=0.000)$, attention $(\mathrm{A})$ and relevance $(\mathrm{R})(\mathrm{r}(273)=0.717$, $\mathrm{p}=273)$, attention $(\mathrm{A})$ and satisfaction $(\mathrm{S})(\mathrm{r}(273)=0.615$, $\mathrm{p}=0.000$ ). Besides, the Pearson Correlation results also demonstrated that the positive correlation between confidence $(\mathrm{C})$ and relevance $(\mathrm{R})(\mathrm{r}(273)=0.504, \mathrm{p}=$ $0.000)$, confidence $(\mathrm{C})$ and satisfaction $(\mathrm{S})(\mathrm{r}(273)=0.418$, $\mathrm{p}=0.000)$. In addition, the results also showed a positive correlation between relevance $(\mathrm{R})$ and satisfaction $(\mathrm{S})(\mathrm{r}$ $(273)=0.698, p=0.000)$. The overall results also show positive association between the ARCS components. The attention component has high degree of correlation to confidence, relevance and satisfaction. Whereas, the students' confidence has moderate association to students' satisfaction.

Table 9. Correlation between ARCS

\begin{tabular}{|c|c|c|c|c|c|}
\hline \multicolumn{6}{|c|}{ Correlations } \\
\hline & & A & $\mathrm{C}$ & $\mathrm{R}$ & $\mathrm{S}$ \\
\hline & Pearson Correlation & 1 & $.580^{* *}$ & $.717^{* *}$ & $.615^{* *}$ \\
\hline \multirow[t]{3}{*}{ A } & Sig. (1-tailed) & & .000 & .000 & .000 \\
\hline & $\mathrm{N}$ & 273 & 273 & 273 & 273 \\
\hline & Pearson Correlation & $.580^{* *}$ & 1 & $.504^{* *}$ & $.418^{* *}$ \\
\hline \multirow[t]{3}{*}{ C } & Sig. (1-tailed) & .000 & & .000 & .000 \\
\hline & $\mathrm{N}$ & 273 & 273 & 273 & 273 \\
\hline & Pearson Correlation & $.717^{* *}$ & $.504^{* *}$ & 1 & $.698^{* *}$ \\
\hline \multirow[t]{3}{*}{$\mathrm{R}$} & Sig. (1-tailed) & .000 & .000 & & .000 \\
\hline & $\mathrm{N}$ & 273 & 273 & 273 & 273 \\
\hline & Pearson Correlation & $.615^{* *}$ & $.418^{* *}$ & $.698^{* *}$ & 1 \\
\hline \multirow[t]{2}{*}{$\mathrm{S}$} & Sig. (1-tailed) & .000 & .000 & .000 & \\
\hline & $\mathrm{N}$ & 273 & 273 & 273 & 273 \\
\hline
\end{tabular}

**. Correlation is significant at the 0.01 level (1-tailed)

\section{Discussion and Conclusions}

The motivational aspects evaluated in this study are based on the ACRS motivation model (Keller, 2010). There are four aspects - which are Attention, Confidence, Relevance, and Satisfaction. As described in the findings, all of these aspects of motivation have high mean scores. The Satisfaction aspect recorded the highest mean score over the other aspects. This indicates that the students' motivation level, especially the satisfaction level is high when using this material. Maslow (1943) explains that satisfaction is a key determinant of one's motivation. Having a high level of satisfaction translates that an individual has a high level of motivation. Based on the result, it illustrates that Arabic language learners are positively impacted by the use of mobile learning, which indicates that most of the participants were very excited and optimistic about Arabic language proficiency, thus this finding is consistent with Norasyikin (2017).

In terms of the effect of mobile learning towards Arabic language proficiency in Malaysia, it indicates that they are relatively optimistic regarding Arabic language education. While the learners viewed Arabic as not an easy language to acquire, mastering Arabic is still a benefit for them. The study also shows that Arabic teachers should play a significant role in seeking more engaging and enticing methods to teach Arabic in order to encourage and inspire students to learn the language and in line with the Fourth Industrial Revolution.

The outcome also indicates that Arabic learners have a high degree of enthusiasm to study Arabic. This result is aligned with the research carried out by Norasyikin (2017) and Ashinida (2010) where the Arabic learners at HIEs showed a high level of motivation to acquire the Arabic language. The students are progressively assessed and motivated by mobile learning. They have opportunities to practice and improve continuously. In each online activity, the instructor can simultaneously give feedback to students' responses through chat box. This aids the learners to enhance their skills as well as obtaining a greater score in their next activities. Using a smartphone in interactive learning can improve students' learning motivation and self-learning after classes. The form of dynamic group formation for a mobile learning system using smartphone during classes and the result is that the students can keep their learning motivation (Pornpan, 2019). Motivation is considered an essential key to learning achievement. The comparison research (Sheldrake, 2016) shows that students with higher self-confidence level obtain higher evaluations (summing up by various factors, such as task scores, grades, anxiety levels, peer comparison, etc.) compared to lower-confident students. Certain types of motivational beliefs are adaptive and do help to promote and sustain self-regulated learning. The mentioned motivational beliefs are: 1) self-efficacy; 2) task value beliefs; and 3) adopting a mastery goal orientation (Pintrich, 1999).

In a nutshell, by exploring the motivations of Arabic language learners towards mobile learning, it is expected that the educational process of Arabic language expertise in this technological age will be greatly expanded and improved. Teachers, educators, decision makers and syllabus writers are in a capacity to consider, select and plan exciting language practices, resources and syllabuses, and to develop or implement effective language teaching methodologies and strategies to preserve and maintain students' optimistic motivations for studying and mastering Arabic language. 


\section{REFERENCES}

[1] Abdelkarim Erradi, H. A. (2012). ArabicTutor: A multimedia m-Learning platform for learning Arabic spelling and vocabulary. International Conference on Multimedia Computing and Systems, 833-838.

[2] Alias, S. S. (2009). A Design and Development Approach to researching Online Arabic Vocabulary Games Learning in IIUM. The 2nd International Conference on e-Learning (ICEL 2009). Shah Alam: UITM Shah Alam.

[3] Alkan, A. T. (2011). Differences between m-learning (mobile learning) and e-learning, basic terminology and usage of mlearning in education. Procedia - Social and Behavioral Sciences, 267-273.

[4] Azhari, A. R. (2005). Peranan Media Internet Arab dalam Meningkatkan Kemahiran Mendengar dan Membaca dalam Kalangan Pelajar Melayu: Satu Tinjauan. Pertanika Journal Social Sciences \& Humanities, 13(1), 83-92.

[5] B. Spolsky. (1969). Attitudinal Aspects of Second Language Learning. Language Learning, 19, 271-85.

[6] Basoglu, E. B. (2010). A Comparison of undergraduate students' English vocabulary learning: Using mobile phones and flash cards. Turkish Online Journal of Educational Technology, 9(3), 1-7.

[7] Budiu, R. (2013). Mobile: Native apps, web apps, and hybrid apps. Retrieved from Retrieved from http://www.nngroup.com/articles/mobile-native-apps/

[8] Chuntao, D. (2010). The study on factors of influencing faculty use of modern instructional technology in higher education. IEEE.

[9] Dong C., Liu X. (2013). A Mobile App for Learning Japanese. In: Lam J., Li K.C., Cheung S.K.S., Wang F.L. (eds) Knowledge Sharing through Technology. ICT 2013. Communications in Computer and Information Science, vol 407. Berlin, Heidelberg: Springer.

[10] Fatimah, W. (2012). Mobile Language Translation Game. International Conference on Computer \& Information Science (ICCIS).

[11] Frasen, J. (2008). Mobile learning: an exploration; State of the art and expectations for the near future. Technical report.

[12] Gilakjani, A. (2012). "A Study on the Impact of Using Multimedia to Imporve the Quality of English Language Teaching.". Journal of Language Teaching and Research. 3, 6:, 1208-1215.8.

[13] Godwin, R. (2011). Emerging Technologies Mobile Apps for Language Learning. Language Learning and Technology. htp:/llt.msu.edu/issues/june2017.

[14] Godwin-Jones, R. (2011). Emerging technologies: Mobile apps for language learning. Language Learning \& Technology, 15(2), 2-11.

[15] Grimus \& Ebner. (2015). Learning and Teaching with mobile device: An approach in higher secondary education in Ghana. International Journal of Mobile and blended learning, 7(2), 17-32. Retrieved from http://www.geocities.com/athens/academy/5578/semtmk/

[16] Hamidin, N. M. (2015). Penggunaan Aplikasi 'Whatsapp'
Dalam Pembelajaran \& Pengajaran (P\&P) Di Kuis. 1st Global Conference On Technology In Language Learning 2015 (Glit2015), 145-152.

[17] Hashemi M., A. M. (2011). What is Mobile Learning? Challenges and Capabilities. Procedia - Social and Behavioral Sciences, 2477-2481.

[18] Ismail Muhamad, Wan Maizatul Akmar Wan Ahmad \& Azman Che Mat. (2013). Sikap dan Realiti Penguasaan Kemahiran Bahasa Arab Pelajar Program j-QAF. GEMA OnlineTM Journal of Language Studies, 13(2), 81-97.

[19] Ismail, N. S. (2016). Learning Arabic Vocabulary using Whatsapp. Kuala Lumpur: Unpublished Master Dissertation International islamic University Malaysia.

[20] Kamila, B. (2016). Multimedia in the English Classroom. World Scientific news.com.

[21] Ketty Chachil, A. E. (2014). Interactive Multimedia-based Mobile Application for Learning Iban. Procedia - Social and Behavioral Sciences 167 (2015), 267 - 273.

[22] Kim, H. K. (2012). Exploring Smart Applications for Effective Mobile-Assisted Language Learning, 1-21.

[23] Kim, P. M. (2008). Pocket School: Exploring mobile technology as a sustainable literacy education option for underserved indigenous children in Latin America. International Journal of Educational Development, 28(4), $435-445$

[24] Kukulska-Hulme, A. (2009). Will mobile learning change language learning? ReCALL, 21(02), 157-165.

[25] Loorbach, N., Peters, O., Karreman, J. \& Steehouder, M. (2015). Validation of the Instructional Materials Motivation Survey (IMMS) in a Self-directed Instructional Setting Aimed at Working with Technology. British Journal of Educational Technology, 46(1), 204-218.

[26] Martinez, S. G. (2010). Using Web Resources to Support Teachers and Students with the Teaching and Practice of Listening Comprehension. Retrieved april 23, 2016, from http://files.eric.ed.gov/fulltext/ED525731.pdf,

[27] Mohamed Amin Embi \& Norazah Mohd Nordin. (2013). Mobile Learning: Malaysian Initiatives \& Research Findings. Dalam Mobile Learning: Malaysian Initiatives \& Research Findings.x. Selangor: Mobile Learning: Malaysian Initiatives \& Research Findings. Dalam Mobile Learning: Malaysian Initiatives \& Research Findings. UKM \& KPT Universiti Kebangsaan Malaysia: 10-12.

[28] Mohd Shahrizal Nasir, Muhammad Sabri Sahrirb, Mohd Firdaus Yahaya. (2015). Pembelajaran Bahasa Arab Menerusi Rancangan Al-Arabiyyah Fi Al-Radio: Analisis Awal Pendengar. Jurnal Sains Humanika, , 83-90.

[29] Mohd Zulkhairi, A. H. (2012). Reka bentuk perisian pembelajaran balaghah Arab peringkat sekolah menengah. Kuala Lumpur: Master's thesis, University of Malaya.

[30] Muhammad Sabri Sahrir, M. F. (2012). EZ-Arabic for Children: A Virtual Learning Resource Tool for Malaysian Primary School. 6th International Conference on University Learning and Teaching. Shah Alam.

[31] Ng S.C., Lui A.K., Wong Y.K. (2015). An Adaptive Mobile Learning Application for Beginners to Learn Fundamental 
Japanese Language. In: Li K.C., Wong TL., Cheung S.K.S., Lam J., Ng K.K. (eds) Technology in Education. Transforming Educational Practices with Technology. Communications in Compu. Berlin: Springer.

[32] Noor Jamaliah Ibrahim, Z. R. (2013). Mobile Application of Al-Quran and Arabic Language for Interactive and Self Learning Assistant for support in j-QAF Learning: A Survey. Seminar Kebangsaan Penyelidikan J-QAF 2013 (pp. 205-218). Bangi: Universiti Kebangsaan Malaysia.

[33] Park, Y. (2011). A pedagogical framework for mobile learning: categorizing educational applications of mobile technologies into four types. International review of research in open and distance learning, 78-102.

[34] Pun, M. (2013). "The Use of Multimedia Technology in English Language Teaching: A Global Perspective.". Crossing the Border: International Journal of Interdisciplinary Studies 1, 1, 29-38.

[35] Rajani Balakrishnan, D. p. (2016). Mobile learning, Effective Integration of new technologies into Existing Model. In J. S. Johan endy Luaran, Envisioning the future of online learning (pp. 317-331). Singapore: Spinger Singapore.
[36] Sandberg, J. M. (2011). Mobile English Learning: An evidence-based study with fifth graders. Computers \& Education, 1334-1347.

[37] Sardi, J. (2009). Pembelajaran Nahu Dalam Bahasa Arab Komunikasi Menggunakan Aplikasi Multimedia Berasaskan Web. Kuala Lumpur: Universiti Malaya.

[38] Shimizu R., Ogawa K. (2014). Which Is More Effective for Learning German and Japanese Language, Paper or Digital? In: Zaphiris P., Ioannou A. (eds) Learning and Collaboration Technologies. Technology-Rich Environments for Learning and Collaboration.LCT 2014. Cham: Springer,

[39] Stockwell, G. (2007). Vocabulary on the move: Investigating an intelligent mobile phone-based vocabulary tutor. Computer Assisted Language Learning, 20(4), 365383.

[40] Upshur, J. (1968). Four Experiments on the Relation between Foreign Language Teaching and Learning. Language Learning, 18, 111-24.

[41] Zawawi Ismail, Ab. Halim Tamuri, Nik Mohd Rahimi Nik Yusoff \& Mohd Ala-Uddin Othman. (2011). Teknik Pengajaran Kemahiran Bertutur Bahasa Arab di SMKA di Malaysia. . GEMA OnlineTM Journal of Language Studies, 11(2), 67-82. 